\title{
Article
}

Mycosphere

\section{Towards a natural classification of Amplistromataceae}

\author{
Daranagama $\mathrm{DA}^{1,2}$, Tian $\mathrm{Q}^{2}$, Liu $\mathrm{XZ}^{1}$ and Hyde $\mathrm{KD}^{2}$ \\ ${ }^{1}$ State Key Laboratory of Mycology, Institute of Microbiology, Chinese Academy of Sciences, No 31 st West Beichen \\ Road, Chaoyang District, Beijing, 100101, People's Republic of China. \\ ${ }^{2}$ Centre of Excellence in Fungal Research, Mae Fah Luang University, Chiang Rai, 57100, Thailand.
}

Daranagama DA, Tian Q, Liu XZ, Hyde KD 2017 - Towards a natural classification of Amplistromataceae. Mycosphere 8(9), 1392-1402, Doi 10.5943/mycosphere/8/9/6

\begin{abstract}
In this study, we revise the family Amplistromataceae (Amplistromatales) based on DNA sequence data derived from living cultures and morphological observation of type and additional specimens from herbaria worldwide. Combined analyses of ITS and LSU sequence data were used to reconstruct phylogenetic relationships of members for the family. We accept three genera; Acidothrix, Amplistroma and Wallrothiella in Amplistromataceae based on the morphology and phylogeny. Modern descriptions and illustrations are provided with notes and a key to the genera is provided.
\end{abstract}

Key words - Amplistromatales - Ascomycetes - phylogeny - taxonomy

\section{Introduction}

Three genera are included in Amplistromataceae, namely Acidothrix Hujslová \& M. Kolařík, Amplistroma Huhndorf et al. and Wallrothiella Sacc. Wallrothiella was re-described by Réblová and Seifert (2004) along with neotypification of its type species Wallrothiella congregata (Wallr.) Sacc. Amplistroma has been segregated from Wallrothiella on the basis of presence of stromatic ascomata. While Amplistroma is stromatic, Wallrothiella does not possess stromatic ascomata. Previous analyses of LSU sequence data reported that Amplistromataceae shares close phylogenetic relationships to the Chaetosphaeriales and Magnaporthaceae, but with no support (Huhndorf et al. 2009). Further phylogenetic analyses also demonstrated a distant relationship to the Meliolomycetidae and Sordariomycetidae and hence Amplistromatales was referred to the Sordariomycetes order incertae sedis until further data was available (Maharachchikumbura et al. (2015, 2016). The latest available molecular phylogeny data refers members of the Amplistromataceae close the Catabotryaceae, while the Amplistromatales were found to cluster within the subclass Diaporthomycetidae (Hongsanan et al. (2017). The subclass Meliolomycetidae was also not accepted by Hongsanan et al. (2017). The objectives of this study were to: 1) resolve the relationships among Acidothrix, Amplistroma and Wallrothiella and 2) to provide a backbone phylogenetic tree for future studies in Amplistromatales based on available ex-type cultures using a multi-gene analysis.

\section{Materials and Methods}

\section{Examination of herbarium materials}


The type specimens of Amplistromataceae were loaned from various herbaria worldwide. Ascomata were rehydrated in $5 \% \mathrm{KOH}$ prior to examination and sectioning. Specimens were examined with a stereo microscope (Motic SMZ 168) and fine forceps were used to remove one or two ascomata, which were mounted in water. Sections were cut by hand with a sharp razor blade and thin sections were cut with a LEICA CM1850 freezing microtome. The sections were transferred to a drop of water and a drop of Melzer's reagent for examination. Observations and photomicrographs of material mounted in water were made with a Nikon Eclipse 80i light microscope fitted with a Cannon 450D digital camera. Measurements were made with Tarosoft (R) Image Frame Work.

\section{Sequence alignment and phylogenetic analyses}

Sequences representing the genera of Amplistromataceae were downloaded from GenBank. The assembled sequences were initially aligned with ClustalW and optimized with MAFFT v. 7 using default settings (Katoh \& Standley 2013) (http://mafft.cbrc.jp/alignment/server/) and adjusted manually where necessary. The initial identities of the newly generated sequences were determined by analyzing them with all available type-derived and authentic sequences of Amplistromataceae. The familial placement was determined by analyzing with strains belong to Amplistromataceae with relation to other families (Table 1).

Table 1 GenBank accession numbers and their strain numbers.

\begin{tabular}{llll}
\hline \multicolumn{1}{c}{ Species } & Strain number & ITS & LSU \\
\hline Amplistroma caroliniana & DOI s.n. & - & FJ532376 \\
Amplistroma caroliniana & BEO9923 & - & FJ532377 \\
Amplistroma erinaceum & AH 43902 & KC907376 & KC907374 \\
Amplistroma guianensis & GJS5740 & - & FJ532380 \\
Amplistroma hallingii & REH7389 & - & FJ532379 \\
Amplistroma longicollis & AH37870 & - & HQ901790 \\
Amplistroma rava & SMH4958 & - & FJ532378 \\
Bambusicularia brunnea & INA-B-92-45 & KM484830 & KM484948 \\
Buergenerula spartinae & ATCC 22848 & JX134666 & DQ341492 \\
Bussabanomyces longisporus & CBS 125232 & KM484832 & KM009154 \\
Catabotrys deciduum & SMH3436 & - & AY346268 \\
Magnaporthe poae & M47 & JF414836 & JF414885 \\
Magnaporthe salvinii & M21 & JF414838. & JF414887 \\
Ophioceras aquaticus & IFRDCC & JQ797440 & JQ797433 \\
Ophioceras commune & 3091 & & \\
Ophioceras dolichostomum & M91 & JX134675 & JX134687 \\
Pseudoproboscispora caudae-suis & CBS 114926 & JX134677 & JX134689 \\
Pseudopyricularia kyllingae & A336-2D & - & AY094192 \\
Pyricularia borealis & HYKB202-1- & KM484876 & KM484992 \\
Slopeiomyces cylindrosporus & 2 & & \\
Submersisphaeria aquatica & CBS 461.65 & KM009162 & KM009150 \\
Wallrothiella congregata & CBS 609.75 & KM484944 & KM485040 \\
Wallrothiella congregata & A95-1B & - & AY094193 \\
\hline & SMH1760 & - & FJ532375 \\
\hline & ANM81 & - & FJ532374 \\
\hline & & & \\
\hline
\end{tabular}

Evolutionary models for phylogenetic analyses were selected independently for each locus using MrModeltest 2.3 (Nylander 2004) under the Akaike Information Criterion (AIC). ML phylogenetic trees were constructed using RAxML 7.4.2 Black Box (Stamatakis 2006, Stamatakis et al. 2008) available in the CIPRES Science Gateway platform (Miller et al. 2010). For the 
combined dataset all free modal parameters were obtained using RAxML with ML estimate of 25 per site rate categories. The RAxML software accommodated the GTR model of nucleotide substitution with the additional options of modeling rate heterogeneity $(\Gamma)$ and proportion invariable sites (I).

Phylogenetic trees and data files were viewed in MEGA 5 (Tamura et al. 2011) and Fig tree v1.4 (Rambaut \& Drummond 2008). Maximum likelihood values (equal to or above 50) are indicated above or below nodes. Faces of fungi numbers are as explained in Jayasiri et al. (2015) and species taxonomy are based on recommendations outlined by Jeewon \& Hyde (2016).

\section{Results}

\section{Phylogenetic analysis of Amplistromataceae}

Twenty-three sequences of Amplistromataceae and other related taxa downloaded from GenBank, were analyzed in this study. Strains of Amplistromataceae lack sequence data so the analysis was limited to LSU data. Maximum likelihood analysis of LSU data (Fig. 1) revealed that taxa of Amplistromataceae resolved as a monophyletic clade, with $100 \%$ ML support. Its sister relationship with Catabotrydaceae is also highly supported. Within the Amplistromataceae two monophyletic groups corresponding to Amplistroma and Wallrothiella were resolved with strong ML support (100\%). Amplistroma clustered with Wallrothiella as a sister group to Catabotrys deciduum in Catabotrydaceae with strong support, forming the order Amplistromatales accommodating Amplistromataceae and Catabotrydaceae. Amplistromatales formed a well-

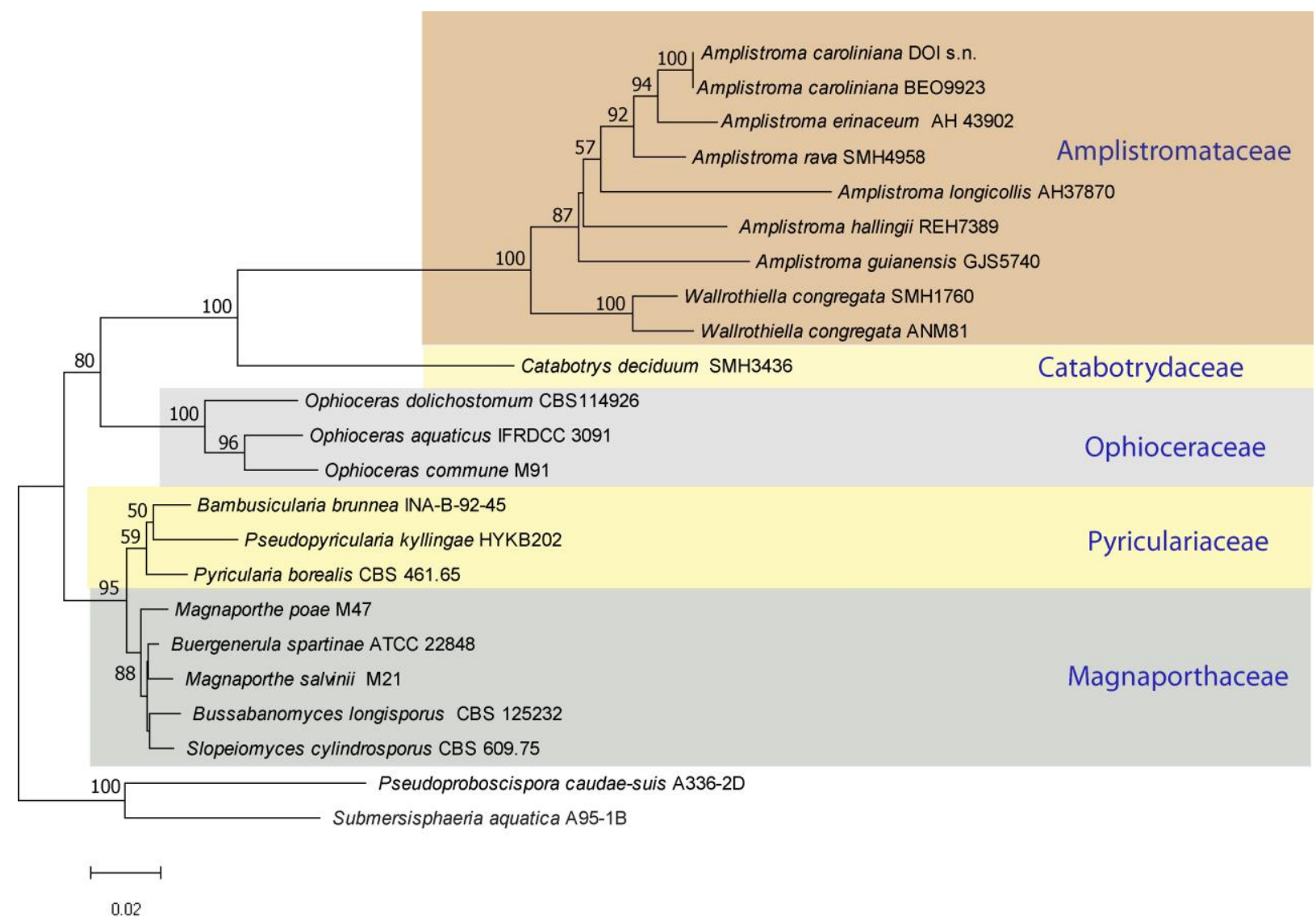

Figure 1 - The best scoring phylogenetic tree based on a combined dataset of ITS and LSU sequence data produced by maximum likelihood analysis. Bootstrap support values for maximum likelihood greater than 50\% are given. The tree is rooted to Pseudoproboscispora caudae-suis and Submersisphaeria aquatica. 
supported clade distinct from known orders within Sordariomycetidae, but shares a sister relationship to the Magnaporthales with strong support (Fig. 1).

\section{Taxonomy}

Amplistromataceae Huhndorf et al., Mycologia 101(6): 905 (2009).

Facesoffungi number: FoF 00618

Saprobic on bark or wood. Sexual morph: Stromata superficial, turbinate, obovoid to irregularly pulvinate, texture soft or sometimes firm, occasionally stromata absent. Ascomata single to clustered, globose or subglobose, polystichous or monostichous, with long necks. Hamathecium comprising hyaline, abundant, filamentous paraphyses. Asci 8-spored, unitunicate, cylindrical to clavate, apical ring not bluing in Melzer's reagent. Ascospores uniseriate, unicellular, globose, hyaline. Asexual morph: acrodontium-like.

Type - Amplistroma Huhndorf et al.

Notes - This family was established to accommodate Amplistroma and Wallrothiella based on molecular and morphological data (Huhndorf et al. 2009). The representative sexual morph of the family contains cylindrical to clavate, pedicellate asci, minute, globose, hyaline ascospores and wide paraphyses that are long-tapering above the asci. Previous studies have reported Amplistromataceae as a monophyletic clade with strong bootstrap and Bayesian support with LSU data, but its sister relationship with Chaetosphaeriales is not supported. The family was earlier referred to the Sordariomycetidae incertae sedis (Huhndorf et al. 2009) until Maharachchikumbura et al. (2015) introduced a new order Amplistromatales to accommodate Amplistromataceae and Catabotrydaceae. Another genus, Acidothrix, known only from its asexual morph was introduced by Hujslová et al. (2014) as an acidophilic, soil fungus in Amplistromataceae. The morphology of Acidothrix acidophila Hujslová \& M. Kolařík is reminiscent of acrodontium-like asexual morphs occurring in Amplistroma species. However, in the phylogenetic analysis, Acidothrix acidophila was placed outside both Amplistroma and Wallrothiella, thus Hujslová et al. (2014) introduced a new genus. In our phylogenetic analysis Amplistromataceae clustered as a monophyletic clade with $100 \%$ bootstrap support from Catabotrydaceae similar to previous analyses (Fig. 1).

Amplistroma Huhndorf et al., Mycologia 101(6): 907 (2009).

Facesoffungi number: FoF 00618

Saprobic on bark or wood. Sexual morph: Stromata superficial, turbinate, obovoid to irregularly pulvinate, texture soft or firm. Ascomata globose or subglobose, arranged in multiple layers, with long necks. Peridium outwardly comprising thin-walled, light brown cells of textura intricata and inwardly comprising thin-walled, hyaline cells of textura intricata. Hamathecium comprising hyaline, abundant, filamentous paraphyses. Asci 8-spored, unitunicate, cylindrical to clavate, pedicellate, ascus apical ring not staining in Melzer's reagent, minute to inconspicuous. Ascospores uniseriate, unicellular, globose, hyaline, thick-walled. Asexual morph: Hyphomycetous, acrodontium-like in culture and occurring on young stromata and near base of older stromata. Conidiophores hyaline to light brown, with whorls of secondary and tertiary branching. Conidiogenous cells arising in verticals or whorls on the branches, lageniform to ampulliform, apex forming elongate rachis, sympodially proliferating, flexuous, with denticulate, blunt, conidiogenous pegs. Conidia light brown to hyaline, pyriform to obovoid, with basal frill (Huhndorf et al. 2009).

Type species - Amplistroma carolinianum Huhndorf et al., Mycologia 101(6): 907 (2009).

Notes - Amplistroma was described with A. carolinianum Huhndorf et al. as the type species. Simultaneously another six species were included in this genus; A. diminutisporum Huhndorf et al., A. guianense Huhndorf et al., A. hallingii Huhndorf et al., A. ravum Huhndorf et al., A. tartareum Huhndorf \& Samuels and A. xylarioides (Pat.) Huhndorf \& Samuels (Huhndorf et al. 2009). Amplistroma erinaceum Checa et al. was later described (Checa et al. 2013), raising the number of species to eight. Species of Amplistroma are distinguished by large stromata of textura intricata, with polystichous ascomata and long necks, that are either erumpent from the stromatal surface or 
form bumps or protuberances. Phylogenetic analysis herein positions Amplistroma as a distinct genus from Wallrothiella with high statistical support (Fig. 1).

Amplistroma carolinianum Huhndorf et al., Mycologia 101(6): 907 (2009).

Fig. 2

Facesoffungi number: FoF 02964

Saprobic on bark or wood. Sexual morph: Stromata 4-8 mm long, 3-7 mm broad, 3-4 mm thick, superficial, irregularly turbinate to obovoid, tan to dull brown or papillate, mature stromata darker with surface covered with densely packed darker brown necks, interior cream-colored, dense, coriaceous. Ascomata 300-325 $\mu \mathrm{m}$ diam, subglobose, immersed in stromatal tissue, polystichous, arranged in 2-3 layers just beneath the stromatal surface, with long papillate necks raised above stromatal surface. Peridium 15-20 $\mu \mathrm{m}$ thick composed of several cell layers, comprising outermost pale brown cell layers and inner hyaline, thin-walled, flattened cell layers. Paraphyses 4-6.5 $\mu \mathrm{m}$ wide, hyaline, abundant, long tapering to narrow apex cells, just above asci. Asci 24-27 $\mu \mathrm{m} \times 3.5-4.5 \mu \mathrm{m}$ spore-bearing part, 10-25 $\mu \mathrm{m}$ long stipe, 8-spored, unitunicate, cylindrical, apex slightly thickened, with apical ring not bluing in Melzer's reagent. Ascospores 2.6-3.4 $\mu \mathrm{m}$ diam., uniseriate or biseriate, unicellular, globose with depressed margin, hyaline, smooth-walled. Asexual morph: acrodontium-like in culture. Conidiophores not observed. Conidiogenesis cells few, dry, similar to phialides. Conidia hyaline, globose.

Material examined - USA, North Carolina, Macon County, Ellicott Rock Trail, off Bull Pen Road, 35u019N, 83u089W, elev. 3000 feet, on bark, 14 October 1990, Y. Doi, A. Y. Rossman, G. J. Samuels (BPI 878925, holotype).

Notes - Two dried cultures were attached to the packet of holotype material where we found conidia. Both cultures contain similar conidia which are hyaline and globose and similar to the ascospores of $A$. carolinianum. Conidiophores were not seen in either culture, no conidiogenesis cells were observed. Remnants of conidiogenesis cells were observed among conidia, which are similar to phialides. According to the phylogenetic analysis in this study, A. carolinianum is closely related to A. erinaceum, but separated as two distinct species (Fig. 1).

\section{Other genera included}

Acidothrix Hujslová \& M. Kolařík, in Hujslová et al., Mycol. Progr. 13(3): 824 (2014).

Facesoffungi number: FoF 02965

Notes - An acidophilic soil fungus isolated from the Czech Republic was placed in the Amplistromataceae based on phylogenetic analysis, and was introduced as a new genus, Acidothrix by Hujslová et al. (2014). This monotypic genus has morphological similarities to acrodontium-like asexual morph, which is produced by species of Amplistroma and Wallrothiella (Hujslová et al. 2014).

Type species - Acidothrix acidophila Hujslová \& M. Kolařík, in Hujslová et al., Mycol. Progr. 13(3): 824 (2014)

Acidothrix acidophila Hujslová \& M. Kolařík, in Hujslová et al., Mycol. Progr. 13(3): 824 (2014).

Facesoffungi number: FoF 02966

Fig. 3

On highly acidic soil. Sexual morph: Undetermined. Asexual morph: Hyphomycetous, sporulation abundant. Conidiophores acrodontium-like, semi-macronematous, single phialide, sometimes macronematous consisting of two to six phialides, sometimes in verticillate arrangement (prostrate). Conidiogenous cells modified to phialides, proliferating sympodially forming a long rachis. Conidia formed on the proliferating conidiogenous cells, single, globose, or ellipsoidal to lacrimose, with hilum, sometimes budding, giving rise to another conidium, first conidium on the phialide is larger.

Notes - Acidothrix acidophila is characterized by the hyphomycete asexual morph producing plane colonies, with abundant aerial mycelium forming floccules and funicules. 
Conidiophores are acrodontium-like, bearing hyaline, globose-ellipsoidal conidia (Hujslová et al. 2014). The sexual morph of $A$. acidophila has not been reported. The type culture is deposited at CBS. A detailed description and a culture based illustration is provided in Hujslová et al. (2014).

Wallrothiella Sacc., Syll. fung. (Abellini) 1: 455 (1882).

Facesoffungi number: FoF 02967

Saprobic on dead bark and decorticated wood. Sexual morph: Ascomata superficial, aggregated into large clusters or solitary, globose to lageniform, short to long beaked, not collapsing when dry, dark brown, surface smooth, sometimes on sparse to abundant subicular hyphae. Subiculum when present, occurring as extensive, white, tomentose hyphae surrounding ascomata. Asci 8-spored, unitunicate, cylindrical to clavate or sometimes ventricose, apical ring not staining in Melzer's iodine reagent, minute to inconspicuous. Ascospores uniseriate, unicellular, globose to slightly depressed globose, hyaline, thick-walled, smooth. Asexual morph: acrodontium-like, produced in cultures. Conidiophores appearing powdery, abundant, aerial, sporulating, arising orthotropically from light brown surface hyphae, erect, differentiated, light brown, with whorls of secondary and tertiary branching towards the apex, Conidiogenous cells arising in verticils or whorls on the branches, narrow lageniform. Conidia light brown, obovoid.

Notes - Wallrothiella was introduced by Saccardo (1882) for Sphaeria congregata Wallr. from Salix wood and has apically collapsing, glossy black ascomata and tiny, globose ascospores. Saccardo did not designate a type. Clements and Shear (1931) selected the material from Salix, Wallrothiella congregata (Wallr.) Sacc as a lectotype. The genus was considered to belong to Sphaeriaceae (von Arx \& Müller 1954), Niessliaceae (Barr 1990) and Trichosphaeriaceae (Samuels \& Barr 1997). However none of these authors were able to locate the type material, thus Réblová and Seifert (2004) designated a neotype by re-describing W. congregata based on two European collections. Réblová and Seifert (2004) considered Wallrothiella as a possible genus for the sexual morph of Brachysporium species. However, they also noted that Wallrothiella differs from Brachysporium in the peridium structure and the morphology of the paraphyses, ascospores and asci. Similar to Huhndorf et al. (2009), the present phylogenetic study (Fig. X) has supported the placement of Wallrothiella in Amplistromataceae based on it morphological similarities to Amplistroma. Wallrothiella comprises 35 species epithets (Index Fungorum 2016).

Type species - Wallrothiella congregata (Wallr.) Sacc.

Wallrothiella congregata (Wallr.) Sacc., Syll. fung. (Abellini) 1: 455 (1882)

ESphaeria congregata Wallr., Fl. crypt. Germ. (Norimbergae) 4: 786 (1833)

Notes - Wallrothiella congregata and species of Amplistroma are similar in morphology in having cylindrical-clavate, pedicellate asci, with minute, globose, hyaline ascospores and wide paraphyses that are long-tapering above the asci. These two genera differ mainly in the size, amount and texture of stromatal structures. Usually species of Amplistroma possess large, fleshygelatinous to cartilaginous stromata with polystichous ascomata, while $W$. congregata has longnecked ascomata but lacks large stromata and develops individually or sometimes gregarious on the substrate. We were unable to observe the materials of $W$. congregata from $F$ and $G$ herbaria, so illustrate W. bromeliae Rehm, which we obtained from S. Refer to the illustration of the neotype of W. congregata with images by Réblová and Seifert (2004) for further details.

Wallrothiella bromeliae Rehm, Hedwigia 40: 103 (1901)

Fig. 4

Facesoffungi number: FoF 02968

Saprobic on wood. Sexual morph: Stromata 200-275 × 300-425 $\mu \mathrm{m}$, superficial, aggregated into groups, fragile, hemispherical glabrous, black, mixed with white fungal hyphae, scattered over the surface, forming black areas, sessile, subcarbonaceous, with white or pale ostiole visible on the surface of the ascomata, with short neck. Ascomata 150-200 $\mu \mathrm{m}$ diam., globose, brown, sometimes with short neck. Peridium $<50 \mu \mathrm{m}$, composed of several layers of brown-black, elongated cells. Paraphyses 3-5 $\mu \mathrm{m}$ wide near the asci, hyaline, numerous, filiform, tapered, embedded in a 

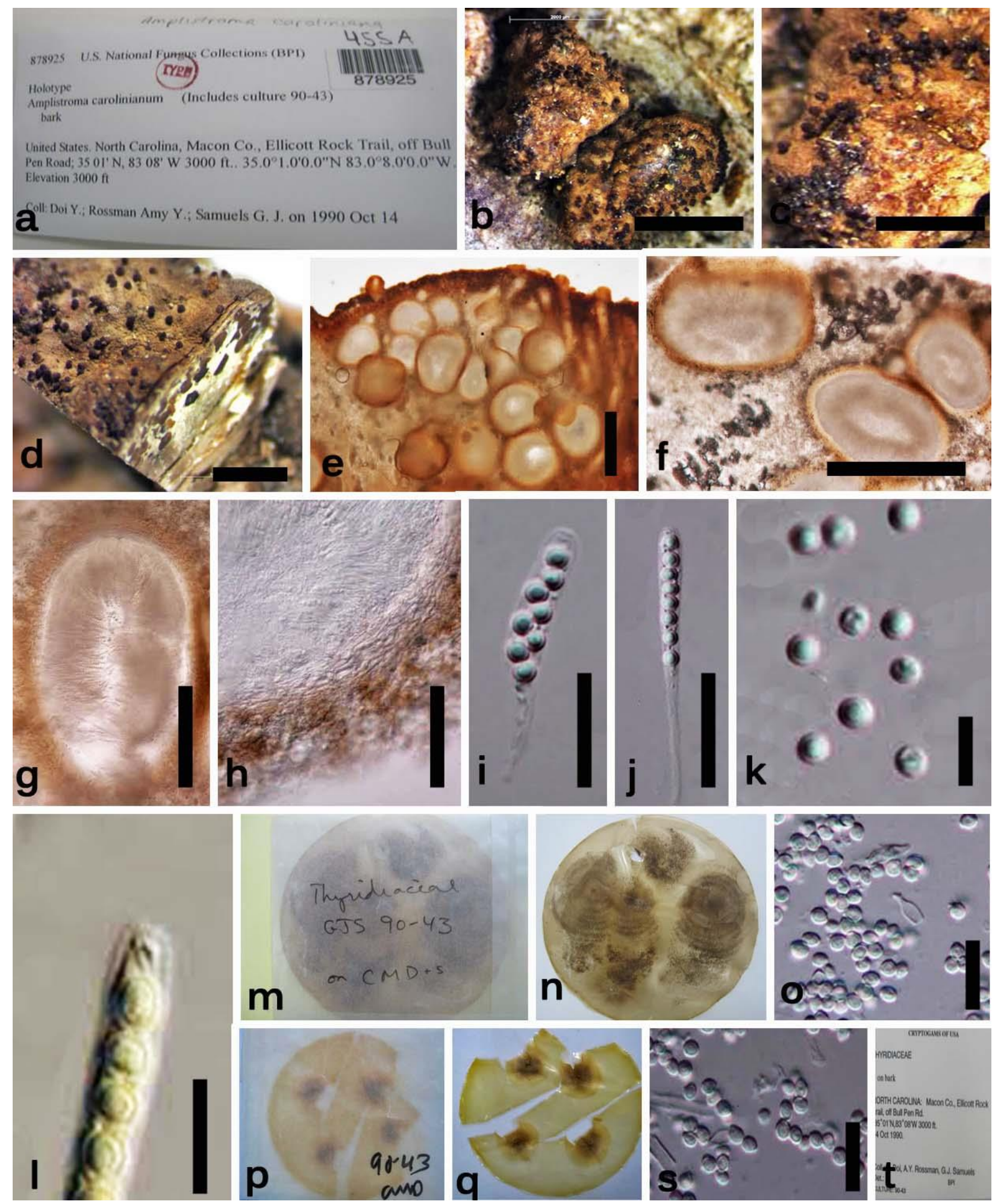

Figure 2 - Amplistroma carolinianum (holotype). a Herbarium details. b Stromata in wood. c Black ostiole necks in stromatal surface. d Cross section through stromata. e Arrangement of ascomata into layers in stromatal tissue. $\mathrm{f}$ Embedded ascomata in stromatal tissue $\mathrm{g}$ Peridium. $\mathrm{h}$ Apex of the asci lacking apical ring. $\mathrm{i}-\mathrm{j}$ Mature asci. $\mathrm{k}$ Ascospores. $\mathrm{i}, \mathrm{m}$ Dried cultures. $\mathrm{n}, \mathrm{o}$ Conidia. - Scale bars: $\mathrm{b}=2000 \mu \mathrm{m}, \mathrm{c}-\mathrm{d}=1000 \mu \mathrm{m}, \mathrm{e}-\mathrm{f}=300 \mu \mathrm{m}, \mathrm{g}=100 \mu \mathrm{m}, \mathrm{h}-\mathrm{j}=20 \mu \mathrm{m}, \mathrm{k}, \mathrm{n}-$ $\mathrm{o}, \mathrm{s}=5 \mu \mathrm{m}$.

gelatinous matrix. Asci 25-40 × 15-20 $\mu \mathrm{m}, 8$-spored, unitunicate, pyriform-clavate, apedicellate or rarely short-pedicellate, sessile, wide at middle, narrowed towards the apex, thick-walled at the 
apex, without apical ring. Ascospores 10-15 × 4-6 $\mu \mathrm{m}$, overlapping uniseriate, unicellular, ellipsoidal-ovate, in face view constricted at the middle, hyaline, guttulate.

Material examined - BRAZIL, Rio de Janeiro, Maua, on Bromelia fastuosa Lindl. (Bromeliaceae), 1896-04, Ule (S-F5832).

Notes - Wallrothiella bromeliae differs from the type W. congregata in having pyriform asci with thick-walled and ovate ascospores. However the ascomata of both species are similar in having superficial, short-beaked ascomata occurring in large clusters (Réblová \& Seifert 2004).

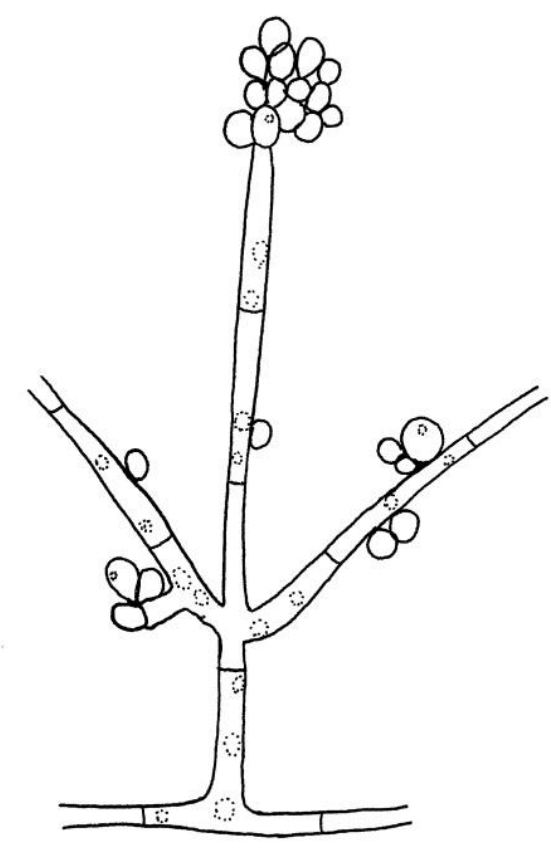

A

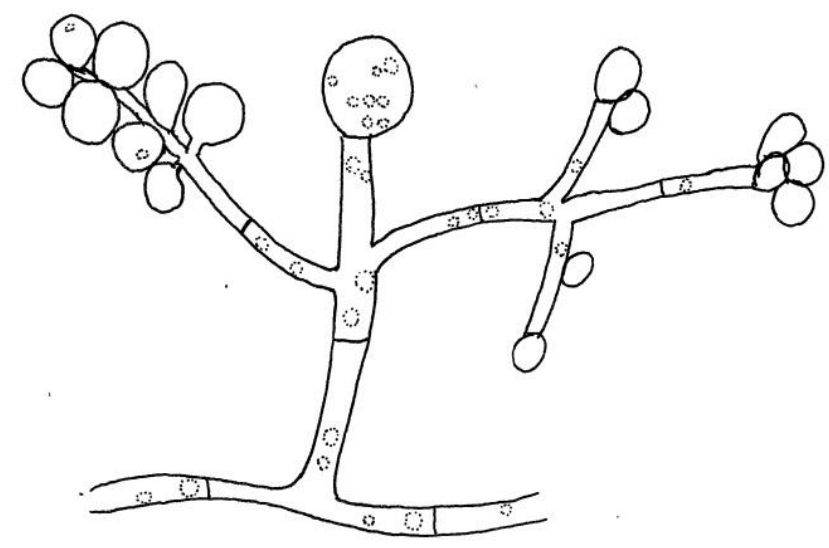

$\mathrm{C}$

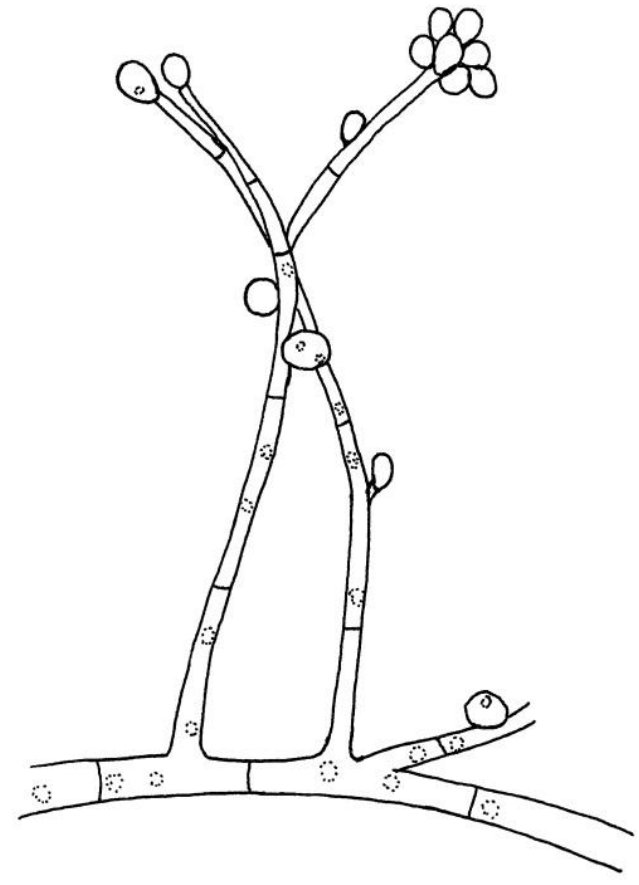

$\mathrm{B}$

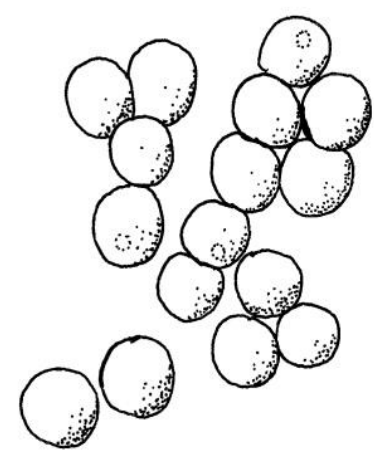

$\mathrm{D}$

Figure 3 - Acidothrix acidophila (redrawn from Hujslová et al. 2014). a, c Conidiophores and conidia. $\mathrm{b}$ Conidia proliferating by hyphae and bearing other conidia. $\mathrm{d}$ Conidia. - Scale bars: $\mathrm{a}-\mathrm{d}=$ $10 \mu \mathrm{m}$. 

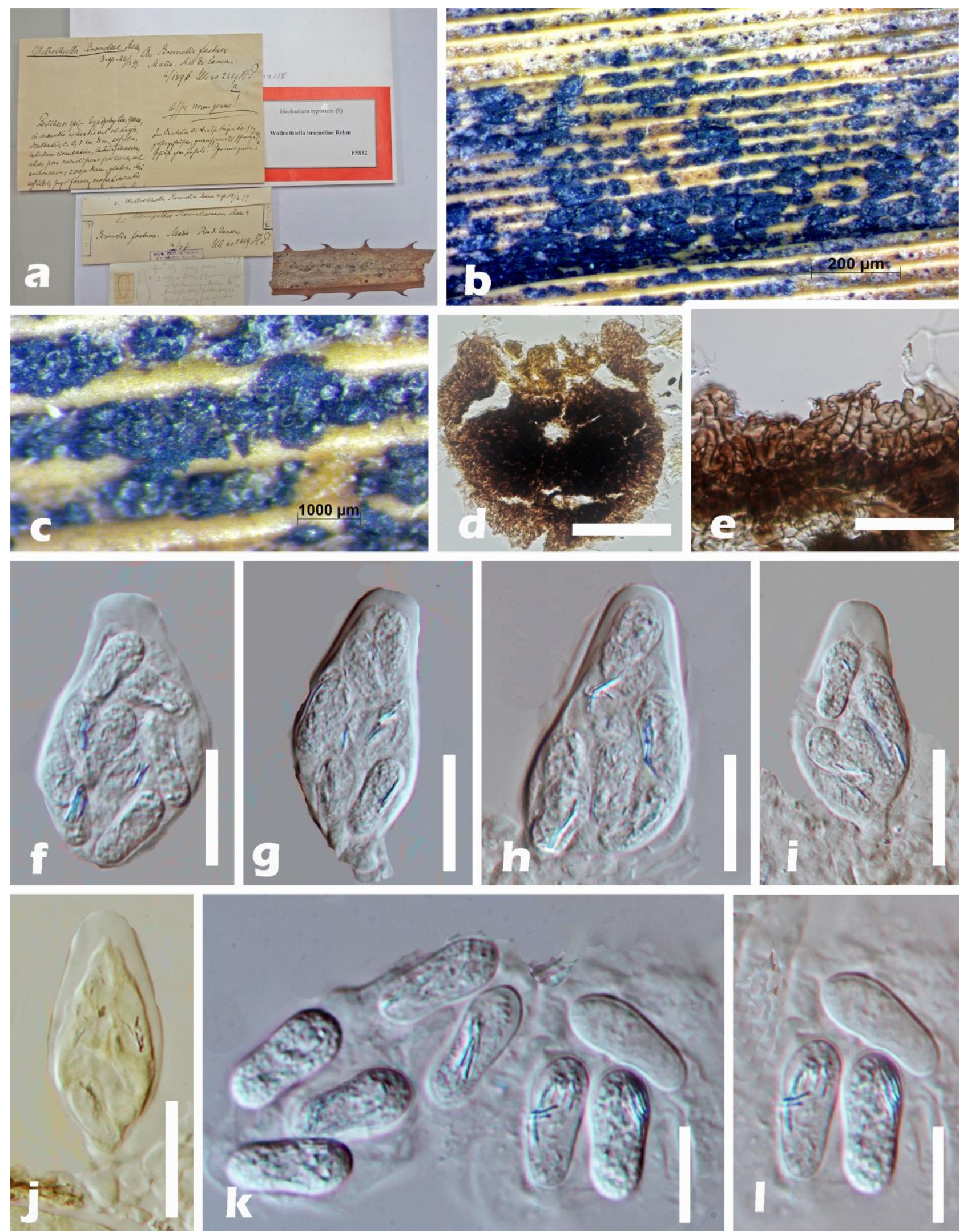

Figure 4 - Wallrothiella bromeliae (F5832). a Herbarium details. b, c Ascomata in wood. d Cross section of ascomata. e Peridium. $\mathrm{f}-\mathrm{i}$ Mature asci. j Asci in Melzer's reagent. $\mathrm{k}-\mathrm{l}$ Ascospores. Scale bars: $\mathrm{b}=200 \mu \mathrm{m}, \mathrm{c}=1000 \mu \mathrm{m}, \mathrm{d}=100 \mu \mathrm{m}, \mathrm{e}=20 \mu \mathrm{m}, \mathrm{f}-\mathrm{j}=20 \mu \mathrm{m}, \mathrm{k}, \mathrm{l}=10 \mu \mathrm{m}$. 


\section{Key to genera of Amplistromataceae}

1. Only asexual morph

Acidothrix

1. Both asexual and sexual morph 2

2. Ascomata arranged in multiple layers, that are either erumpent from the stromatal surface or form protuberances, forming large stromata of textura intricate Amplistroma

2. Ascomata develop individually or are gregarious on the substrate, but do not form large stromata Wallrothiella

\section{Discussion}

Amplistromataceae comprises two genera namely Amplistroma Huhndorf et al. and Wallrothiella Sacc. The genus Wallrothiella was re-illustrated by Réblová and Seifert (2004) and neotypified with Wallrothiella congregata (Wallr.) Sacc., the generic type species. Amplistroma has been segregated from Wallrothiella based on the presence of stromatic ascomata. Catabotrydaceae is a monotypic family with Catabotrys as its type genus. However Wallrothiella lack stromatic ascomata, while Amplistroma is considered as stromatic. LSU phylogenetic analysis by Huhndorf et al. (2009) indicate that Amplistromataceae has no close relationship with Chaetosphaeriales or Magnaporthaceae. In phylogenetic analyses of Maharachchikumbura et al. (2015, 2016) Amplistromatales appears to be distantly related to Meliolomycetidae and Sordariomycetidae and thus were referred to the Sordariomycetes order incertae sedis. Maharachchikumbura et al. (2015) introduced a separate order, Amplistromatales, comprising two families, Amplistromataceae and Catabotrydaceae. In our phylogenetic analysis similar results are obtained and hence we treat Amplistromatales in Sordariomycetes incertae sedis. Hongsanan et al. (2017) treated Catabotrydaceae in Sordariomycetes, families incertae sedis based on molecular dating evidence. It was also evident that Catabotryaceae has diverged from Amplistromatales ca. 165 MYA (Hongsanan et al. 2017). Hujslová et al. (2014) included Acidothrix, an asexual, soil fungus in the Amplistromataceae. The morphology of Acidothrix acidophila Hujslová \& M. Kolařík is similar to the acrodontium-like asexual morphs occurring in Amplistroma species. However in Hujslová et al. (2014) Acidothrix as established as a new genus. In our phylogenetic analysis, we have included the strain of Acidothrix acidophila (MH566) and it resulted in a long branch attraction, which was basal to the Amplistromataceae clade (results not shown). Thus we have excluded the strain from our analysis yet we consider it as a genus in Amplistromataceae due its morphological similarities. Further isolation of the species is thus recommended to establish appropriate phylogenetic relationships and it is noteworthy that the sexual morph of this species is yet to be identified.

\section{References}

Barr ME. 1990 - Podromus to nonlichenized, pyrenomycetous members of class Hymenoascomycetes. Mycotaxon 39, 43-184.

Checa J, Blanco MN, Moreno G, Alvarado P, Esquivel E. 2013 - Amplistroma erinaceum, a new species and its anamorph from Panama. Mycological Progress 13, 277-283.

Clements FE, Shear CL. 1931 - The genera of fungi. H.W. Wilson, New York, USA.

Hongsanan S, Maharachchikumbura SSN, Hyde KD, Samarakoon MC, et al. (2017) An updated phylogeny of Sordariomycetes based on phylogenetic and molecular clock evidence. Fungal Diversity 84:25-41.

Hujslová M, Kubátová A, Kostovčík M, Blanchette RA et al. 2014 - Three new genera of fungi from extremely acidic soils. Mycological Progress 13, 819-831.

Huhndorf SM, Miller AN, Greif M, Samuels GJ. 2009 - Amplistroma gen. nov. and its relation to Wallrothiella, two genera with globose ascospores and acrodontium-like anamorphs. Mycologia 101, 904-919. 
Jayasiri SC, Hyde KD, Ariyawansa HA, Bhat J et al. 2015 - The Faces of Fungi database: fungal names linked with morphology, phylogeny and human impacts. Fungal Diversity 74, 3-18.

Jeewon R, Hyde KD. 2016 - Establishing species boundaries and new taxa among fungi: recommendations to resolve taxonomic ambiguities. Mycosphere 7, 1669-1677.

Katoh K, Standley DM. 2013 - MAFFT multiple sequence alignment software version 7: improvements in performance and usability. Molecular Biology and Evolution 30, 772-780.

Réblová M, Seifert KA. 2004 - Cryptadelphia (Trichosphaeriales), a new genus for holomorphs with Brachysporium anamorphs, and clarification of the taxonomic status of Wallrothiella. Mycologia 96, 343-367.

Maharachchikumbura SSN, Hyde KD, Jones EBG, McKenzie EHC et al. (2015) Towards a natural classification and backbone tree for Sordariomycetes. Fungal Diversity 72, 199-301.

Maharachchikumbura SSN, Hyde KD, Jones EBG, McKenzie EHC et al. (2016) Families of Sordariomycetes. Fungal Diversity 79, 1-317.

Miller MA, Pfeiffer W, Schwartz T. 2010 - Creating the CIPRES Science Gateway for inference of large phylogenetic trees. In: Proceedings of the Gateway Computing Environments Workshop (GCE), 14 Nov. 2010, New Orleans, Louisiana.

Nylander JAA. 2004 - MrModeltest 2.0. Program distributed by the author. Evolutionary Biology Centre, Uppsala University.

Rambaut A, Drummond A. 2008 - Fig Tree: Tree figure drawing tool, version 1.2. 2. Institute of Evolutionary Biology, University of Edinburgh.

Samuels GJ, Barr ME. 1997 - Notes on and additions to the Niessliaceae (Hypocreales). Canadian Journal of Botany 75, 2165-2176.

Saccardo PA. 1882 - Sylloge Fungorum 1, 1-763.

Stamatakis A. 2006 - RAxML-VI-HPC: maximum likelihood-based phylogenetic analyses with thousands of taxa and mixed models. Bioinformatics 22, 2688-2690.

Stamatakis A, Hoover P, Rougemont J. 2008 - A rapid bootstrap algorithm for the RAxML web servers. Systematic Biology 57, 758-771.

Tamura K, Peterson D, Peterson N, Stecher G, Nei M, Kumar S. 2011 - MEGA5: molecular evolutionary genetics analysis using maximum likelihood, evolutionary distance, and maximum parsimony methods. Molecular Biology and Evolution 28, 2731-2739.

von Arx JA, Muller E. 1954 - Die Gattungen der amerosporen Pyrenomyceten. Beiträge zur Kryptogamenflora der Schweiz11, 1-434. 